\title{
Luminous Environmental Comfort in Classrooms in Northeast Brazil
}

\author{
Gylnara Kylma Feitosa Carvalhêdo Almeida ${ }^{1}$, Will Ribamar Mendes Almeida², \\ Miguel Jânio Costa Ferreira ${ }^{3}$, Gabriela Ferreira Carvalho ${ }^{4}$, Guilherme Gonçalves Silva Pinto ${ }^{5}$, \\ Ana Lourdes Avelar Nascimento ${ }^{6}$ and Maria Claudia Gonçalves ${ }^{7}$ \\ ${ }^{1}$ Universidade CEUMA - UniCEUMA, São Luís-Maranhão, Brasil \\ gylnara@gmail.com \\ ${ }^{2}$ Universidade CEUMA - UniCEUMA, São Luís-Maranhão, Brasil \\ will.almeida@ceuma.br \\ ${ }^{3}$ Universidade CEUMA - UniCEUMA, São Luís-Maranhão, Brasil \\ mfpersonal2010@hotmail.com \\ ${ }^{4}$ Universidade de São Paulo - USP, Ribeirão Preto, São Paulo - São Paulo, Brasil \\ gabriela.fisioterapia@gmail.com \\ ${ }^{5}$ Faculdades Integradas do Planalto Central, Brasília, Distrito Federal, Brasil \\ guilhermegoncalves19@hotmail.com \\ ${ }^{6}$ Universidade CEUMA - UniCEUMA, São Luís-Maranhão, Brasil \\ analouavelaravelar@hotmail.com \\ ${ }^{7}$ Universidade CEUMA - UniCEUMA, São Luís-Maranhão, Brasil \\ mcgfisio0@gmail.com
}

\begin{abstract}
The objective of this article was to evaluate the light conditions in classrooms at a school in the northeast of Brazil and their influence on learning. The illuminance of the rooms was evaluated during solstices and equinoxes. We used NBR 15215-04 and measured light a 16 points using a digital lux meter. Also, perceptions of luminous comfort were ascertained through a questionnaire administered to teachers and students. Only $18 \%$ of the evaluated points were within the range of luminosity considered adequate according to the NBR, and the perceptions of teachers and students coincided with the technical results, as the light levels were considered unsatisfactory. According to the teachers, poor lighting affects school activities and the behavior of students, and we recorded complaints of visual discomfort and headaches. The lighting in the evaluated rooms was not adequate in terms of the comfort and quality of student learning. Low-cost strategies aimed at improving visual comfort-and, consequently, student learning-are suggested.
\end{abstract}

Keywords: Luminous comfort; Classroom; Illuminance distribution 


\section{Introdution}

It is essential that all buildings' physical designs allow tasks to be carried out in each place in a way that ensures user comfort. It is said that a person is comfortable in relation to an event or phenomenon when they can observe or feel it without any worry or discomfort (CORBELLA and YANNAS, 2003), making it clear that environmental comfort has a link to the well-being and physical and psychological sensations of individuals in a given environment.

It has been widely demonstrated that a comfortable environment increases workers' productivity, and this concept can also be extended to students (TOYINBO ET AL., 2016; HAVERINEN-SHAUGHNESSY ET AL., 2015; LEE ET AL., 2012). Although the number of environmental comfort studies in school buildings is not comparable to those in office spaces, a review by Zomorodian et al. (2016) revealed that 48 articles on the subject were published from 1969 to 2015, mainly in Europe.

Environmental comfort is predominantly linked to variables that represent an important part of the well-being and satisfaction of teachers and students. Teachers need healthy teaching environments to perform their functions in a supportive way, and students need such environments for learning. In this way, excess noise, vibrations, and problems with illumination and heat are factors that can impair health (BATISTA ET AL., 2010; MOURA ET AL., 2016; HUNTER ET AL., 2015).

Classroom lighting is an important aspect for students and teachers alike. Visual comfort in classrooms has been pointed out (HERACLEOUS, 2017; WINTERBOTTOM ET AL., 2009) as a crucial factor for learning and is recognized as playing a role in improving the educational process. In addition, it has been found that children's behavior can be influenced by ambient light (SHAPIRO ET AL., 2001).

With respect to lighting, it is recommended that the illuminance at any point in a workspace is no less than $70 \%$ of the average determined by the Brazilian Regulatory Norm (NBR) 5382/85 (ABNT, 1985). Illuminance is expressed in lux (lx) and is the magnitude used for the evaluation of visual comfort. It is the ratio between the luminous flux received by the surface and the area considered. Drastic changes in lighting lead to stressful visual exertion and discomfort (ABNT, 1992). Thus, a learning environment requires adequate lighting, for both teacher and students (BATISTA ET AL., 2010; DALVITE ET AL., 2007).

Employing the fundamentals of environmental comfort in architectural projects is essential for maintaining the health of users in a given environment (FARIAS, 2009), and in fact, adequate lighting helps to relieve depression, improve sleep quality, and improve human performance, such as through the regulation of melatonin and cortisol hormones (SOUZA, 2012).

It is known that human comfort is not only objective but is also dependent on many factors and sub-factors (FRONTCZAK ET AL., 2011; CASTILLA ET AL., 2017). Therefore, the analysis of environmental comfort is particularly complex because it is a multidisciplinary subject that requires careful research in several fields, such as engineering, psychology, statistics, medicine, and educational science. Therefore, a combination of measurements and questionnaires provides a more complete view of environmental quality and the well-being of users, since these users are generally not satisfied with the internal conditions, even when comfort standards are met (RICCIARDI ET AL., 2012). Therefore, there is a need to use objective research tools, such as measurements, alongside subjective ones, such as interviews.

In order for learning to take place, it is necessary that, in addition to the basic elements (teacher, students, contents, and a pedagogical strategy), there is also harmony between the built environment and its users, through both 
environmental and ergonomic comfort. In light of this, it is seen that functional lighting is one of the fundamental items that allows a person to fully enjoy a space in which visual experiences are predominant. If it is not properly planned, there may be deficits in learning as well as health damage (SERRÃO, 2014). Therefore, the learning environment must present adequate environmental comfort to guarantee the well-being of teachers and students, besides stimulating the adequate development of teaching activities and preventing health problems.

The objectives of this study are to evaluate the illuminance of classrooms at a day care center/school, to analyze the perceptions of its users (students and teachers), and to verify the influence of comfort on the learning process.

\section{Methods}

\subsection{Characteristics of the study site}

The school under study was founded in 1931 and was initially an orphanage intended to house the children of leprosy patients in the Anil district of São Luís (MA). It currently functions as a day care center/school, serving 60 children aged between 6 and 10 years, with 4 rooms in operation. Structurally, the school has the architectural features of an old farmhouse, with unlined rooms, half walls, red ceramic floors, and walls painted with green and light pink stripes. It still has a ceramic tile roof. The building is segmented into one administrative block and two classroom blocks, one of which features a dining room, kitchen, outdoor court, and patio (see Figure 1). It should be noted that the façades of the greater extension used in the analysis of the solar incidence are oriented towards the northeast and southwest in the case of room A, and northwest and southeast for room B. In Figure 1, the locations of the classrooms used in the study are marked as rooms A and B.

Figure 1 - Location of classrooms A and B in Educandário

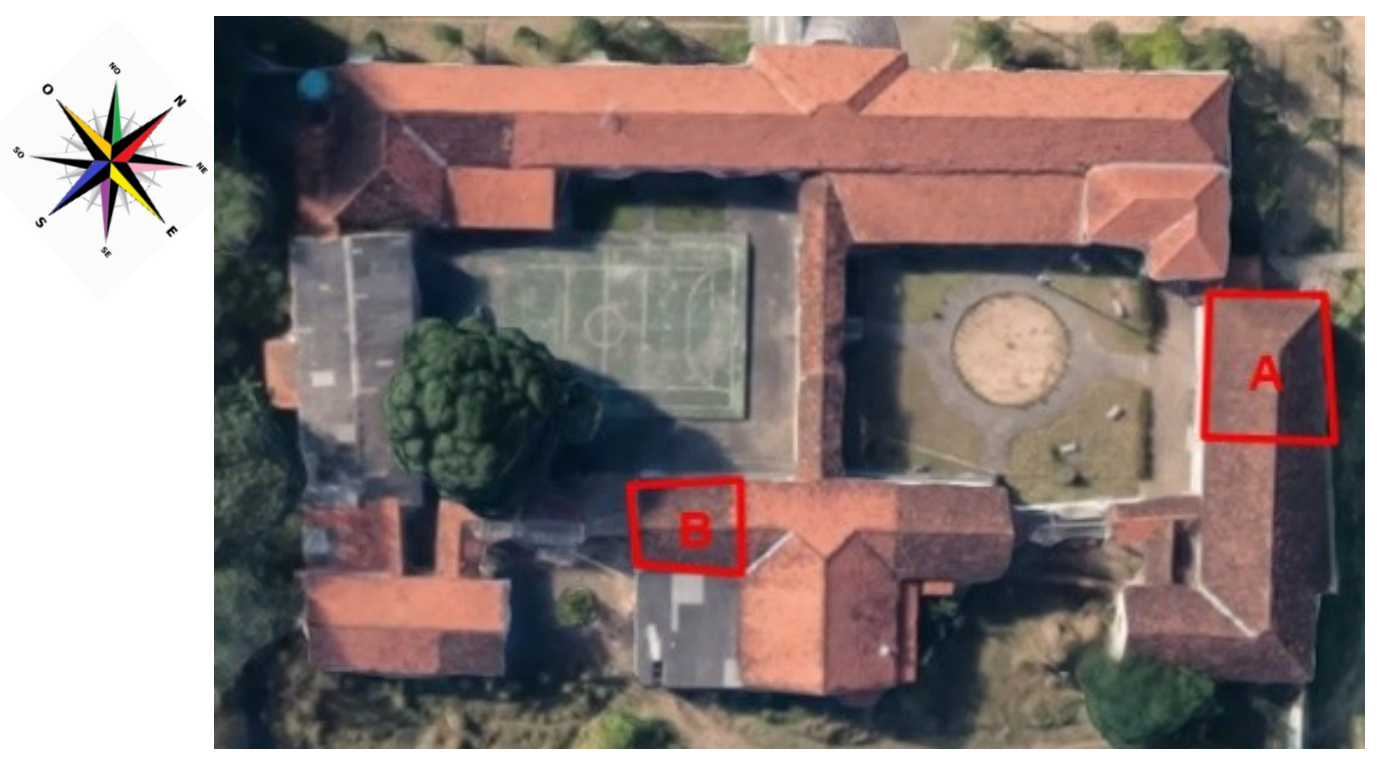

Source: Google Maps 


\subsection{Sample calculation and inclusion and exclusion criteria}

Considering the number of students and teachers attending the nursery $(n=65)$, we set a significance level of $95 \%$, a sampling error of $5 \%$, and a $12 \%$ increase for eventual sample losses. A sample of 43 individuals (students and teachers) participated in the questionnaire/interviews about their perceptions of light-related comfort and how much it influences the accomplishment of educational activities. We included only teachers and students who conduct activities in the analyzed rooms and excluded teachers who did not wish to participate in the research and students who presented cognitive alterations that impeded their participation.

\subsection{Methodological procedures}

The research methodology was developed following four phases of work: bibliographic, documentary, field, and laboratory research. The bibliographic research allowed the development of the theoretical reference and related it to other studies. The documentary research consisted of the collection of data on the school and its students and teachers. During the field research carried out in the classrooms, information was collected on the architectural typologies characterizing the classrooms and their openings. Subsequently, measurements of the illuminance levels in the classrooms were taken and questionnaires/interviews were carried out to evaluate the lighting and verify the satisfaction of the users. In the laboratory research phase, we statistically analyzed the collected data. The field investigation, corresponding to the stage of interview and application of the questionnaire, began after authorization by the Research Ethics Committee of CEUMA University (CAAE: 80335117.4.0000.5084), in agreement with the National Health Council, Resolution 416/2012.

\subsection{Illuminance measurement}

Initially, based on NBR 15215-04 (ABNT, 2004), we divided the school space into a mesh with 16 measurement points for adequate characterization of the illuminance from natural and artificial light in the working plane at a height of $0.50 \mathrm{~m}$ from the floor. We used the center of each area for the measurement (see Figure 2).

Figure 2 - Location of measurement points, rooms A and B. L1 and L2 = lamps with two fluorescent tubular T8 32W lights.
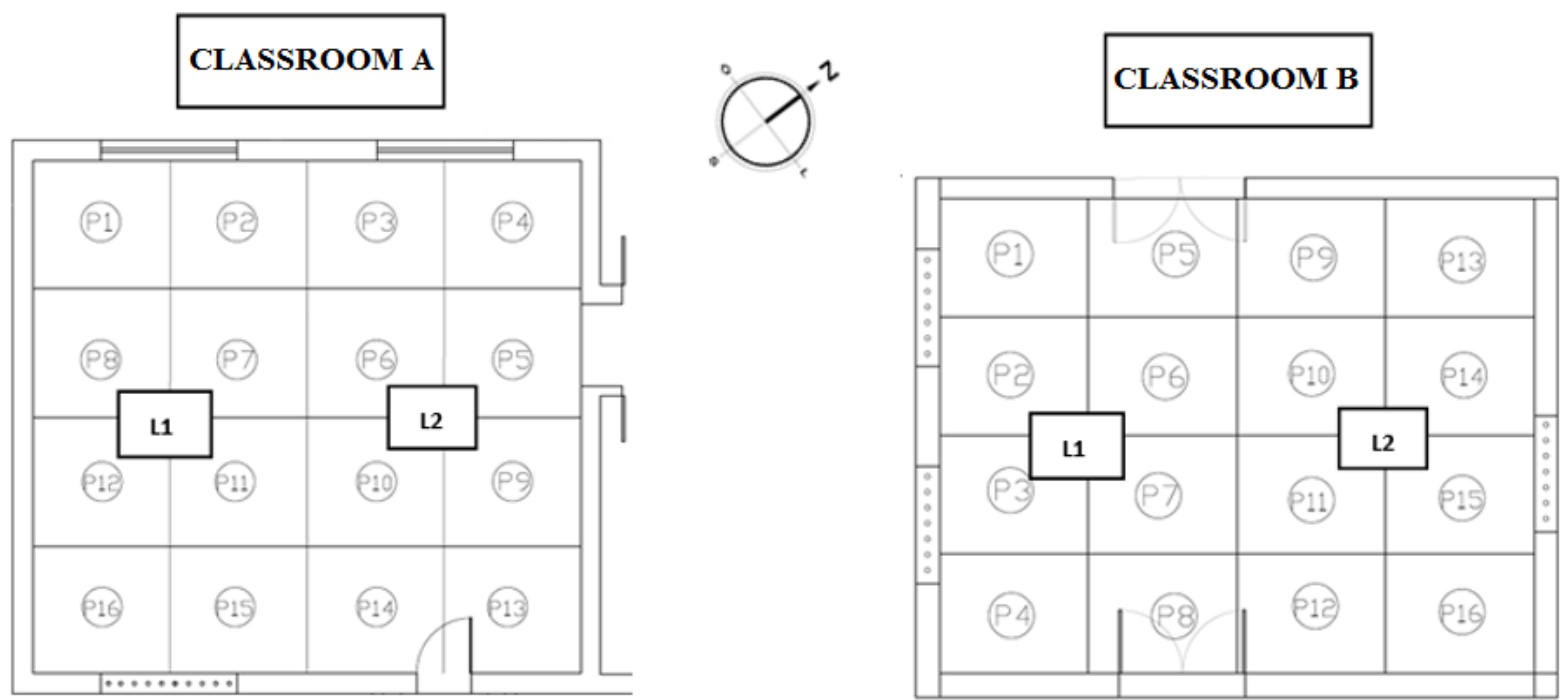
Light measurements were taken using a Sunche portable digital luximeter, model HS1010, with scale variation between 0 and 200,000 lux. We obeyed the method of the comfort of light analysis, according to NBR 5413 and NBR 15.215

The illuminance measurements took place on days close to the winter and summer solstices (06/20/2016 and $12 / 20 / 2016$, respectively), and at the autumn and spring equinoxes (03/20/2017 and 09/22/2017, respectively). In each of the rooms studied, we took four daily measurements, two in the morning (at 8 and 11 o'clock) and two in the afternoon (at 2 and 5 o'clock), according to the recommendations of the current standards. Measurements were taken at 16 points with the lamps on, and the lighting was a combination of natural and artificial light. According to NBR 5413, the ideal illuminance value for classrooms with children pursuing daily learning tasks (reading, writing, painting, etc.) is 300 lux.

\subsection{Assessment of perceptions of ambient light comfort}

The teachers' and students' perceptions of luminous environmental comfort were ascertained using a questionnaire adapted to the needs of each group investigated (GEMELLI, 2009; OCHOA, 2012). The questionnaire administered to the students, according to age, was of the closed type, and the interviews with the teachers were of the open type. Measurements of the light variable were performed using commercial equipment, Sunche portable digital luximeter, model HS1010, with scale variation between 0 and 200,000 lux, and obeyed the method of the Comfort of Light Analysis according to NBR 5413 and NBR 15.215.

\section{Results}

We evaluated 40 students aged 6 to 10 years; $60 \%$ belonged to the female gender and $40 \%$ to the male gender. We also evaluated 3 female teachers, aged 25 to 40 years, with a mean of 6 years of experience in teaching at the chosen educational institution.

According to NBR 5413, between 250 and 350 lux is a suitable brightness level for classrooms. From the measurement of the illuminance, we found that in the 16 sites evaluated in room A, a mean illuminance of 335 lux and 313 lux was obtained based on the measurements in the summer and winter solstices, respectively, and a mean illuminance of 363 lux and 522 lux in the autumn and spring equinoxes, respectively. Of the total of 16 points evaluated during the equinoxes and solstices $(n=64)$, only $13(20.3 \%)$ presented adequate illuminance, $30(46.9 \%)$ were above the recommended level, and 21 (32, 8\%) were below it. Likewise, for room B, an average illuminance of 267 lux and 350 lux was verified in the summer and winter solstices, respectively, and mean illuminance of 268 lux and 378 lux in the autumn and spring equinoxes, respectively. Of the total evaluated points, only $13(20.3 \%)$ presented adequate illuminance, with 21 (32.8\%) of them above and 30 (46.9\%) below the appropriate NBR variation.

As shown in Figure 3, where the occurrence of luminosity is represented by over a year of measurements, only $18 \%(64 \%-46 \%)$ of the values obtained in room A and 18\% (69\% - 51\%) in room B represent a comfortable condition; $46 \%$ in room $\mathrm{A}$ and $51 \%$ in room $\mathrm{B}$ are in a low-light condition and $36 \%$ in room $\mathrm{A}$ and $31 \%$ in room $\mathrm{B}$ have light incidence above a comfortable level. 
Figure 3 - Histogram of frequency and cumulative probability of illuminances, solstices, and equinoxes, from rooms A and $B$

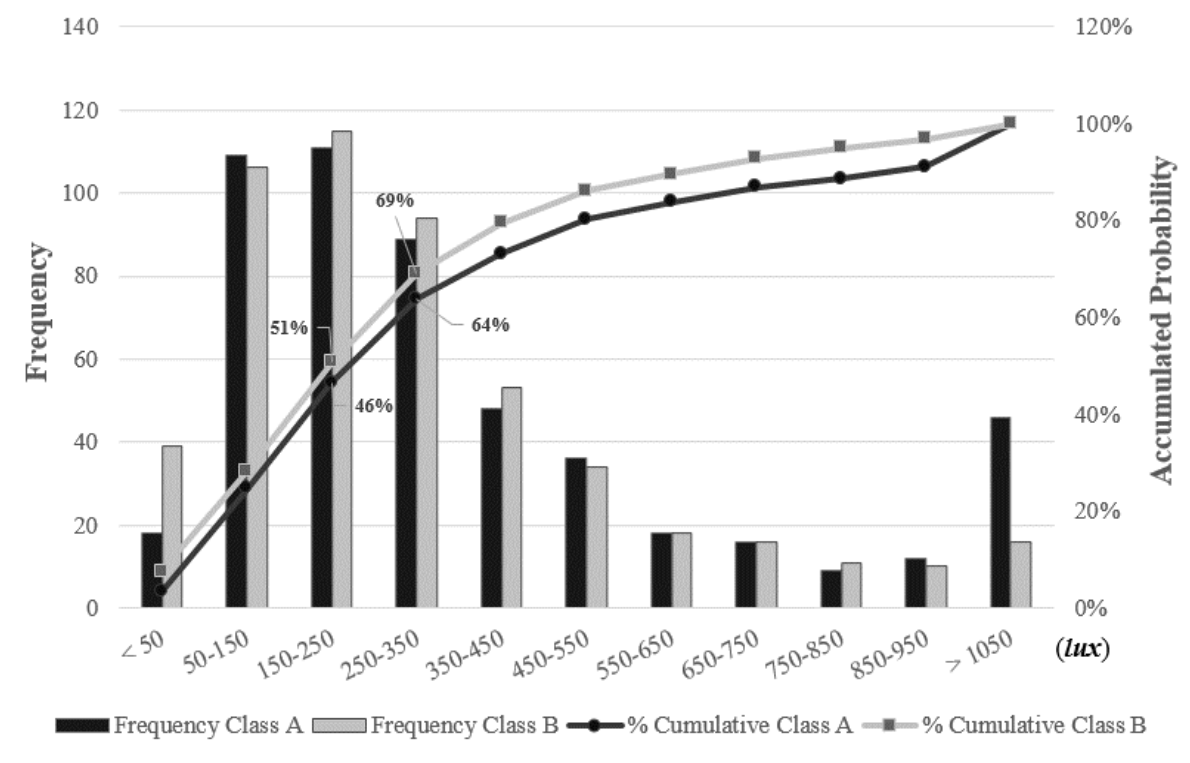

Concerning the perception of light comfort, we found that $70 \%$ of students in room $\mathrm{A}$ and $85 \%$ in room $\mathrm{B}$ considered the lighting as inadequate; $10 \%$ of students in room A and $60 \%$ in room B reported that they have difficulty seeing what is written on the board; $72 \%$ of students in room A and $90 \%$ in room B reported that they need to use lamps to do their activities.

When asked about the impact of lighting on the educational environment, we found that two teachers (room B) believed that lighting moderately influences the activities and behaviors of the students, and one (room A) who stated that lighting influenced nothing in the development of the class. Two teachers (room B) agreed that there is great difficulty in completing tasks due to complaints of headaches or sleepiness. It is important to note that all teachers noticed isolated cases of sleepiness or lethargy due to a lack of light, and there were likewise visual irritations and headaches caused by excessive light.

When asked "Is there any discomfort or lack of clarity when the door of the room is closed?," two teachers stated that if this happens, it is so dark that it is impossible to work (room B) and carry out any activities. The third teacher said that the classes normally continue as long as it is not rainy or cloudy (room A).

\section{Discussion}

It is in the Elementary School that the first steps in the academic life of a child, along with play activities, aim to develop their cognitive and socialization capabilities using different stimuli. In this way, the illumination of education spaces should ensure the best use of these activities and the development of children's perceptions, especially visual perception, because they are in the stage of visual memory formation and need to receive accurate information.

The results of this study demonstrated that most of the points evaluated in the two classrooms were not suitable for the activities performed there, according to NBR 5413; most points were significantly below the recommended level and some were well above it. In this sense, Batista et al. (2010) emphasized that in a teaching environment, adequate lighting is vital to allow the execution of visual tasks and to ensure comfort. Inadequate classroom lighting can lead to visual impairment, resulting in fatigue, headaches, and irritation of the eyes. 
The distribution of observed illumination may have been related to the spatial aspects of the classrooms, such as windows that occupied the entire length of the wall adjacent to the blackboard, or the absence of a curtain, sun shade, or awning that would reduce the direct incidence of solar rays inside the room, which can cause blurring of images and text written on the board. In this way, we highlighted the need for adjustments to the brightness of the school's classrooms, due to the impact that light can have on the health of the teachers and students. These adjustments could include the use of openings or windows that favor a good distribution of natural light and positioning windows in opposite walls so as to avoid areas with excessive illuminance or shading.

Vianna and Gonçalves (2001) recommend that for a good distribution of illuminance there is a need to adopt a lateral lighting system for classrooms, where the openings are symmetrical and are on opposite walls. They also recommend the use of direct resources to avoid the glare, such as vegetation in outdoor areas, shades, or fine curtains.

However, care needs to be taken to avoid drastically reducing the levels of illumination inside the rooms; so, in the rooms studied, the amount of luminance should be increased, but not so much that it creates glare. By means of a simulation using the FAEL-LITE 10.0 program, we verified that for classrooms A and B, adequate indexes of average illuminance will be required. It will be necessary to use 6 light fixtures that have control features, reflectors, and fins, as well as parabolic lamps with 40W T8 led tube lights, mainly on the walls and around the school board. In order to optimize the efficiency of the luminaires, priority should be given to the use of light colors in the environment in order to reduce the loss of illuminance that normally occurs on dark surfaces.

Some kind of control could also be used to integrate natural light into the artificial lighting system, so that adequate use can be made of both. This could be accompanied by automated features so that it is controlled in a programmed way to consider the changes in illuminance due to levels of sunlight at different times of the day, as if it worked as a compensatory illuminance system (NBR 8995-1: 2013).

The perceptions of comfortable light of both the teachers and students coincided with the results obtained from the measurements and statistical analyses. In both rooms, the vast majority of users reported that they considered the internal lighting to be inadequate to provide satisfactory light for the execution of tasks. Further, all teachers reported isolated cases of sleepiness or lethargy, visual irritation, and headaches that were possibly caused by insufficient or excessive illumination.

The findings of this article reinforce the need for more attention to comfort and environmental quality in elementary schools. Considering that children spend an average of about 1,300 hours in classrooms each year (JUSTER ET AL., 2004), the internal environmental comfort of classrooms should be given more attention, with lighting, air quality, temperature, and spatial organization all being taken into account (FRONTCZAK and WARGOCKI, 2011). If the conditions in classrooms are compromised, learning and academic activities may also be compromised (Schneider et al., 2002). Furthermore, environmental conditions become particularly worrisome since children's immune systems are still being formed, which predisposes them to more risks than adults (SOUZA ET AL., 2012). The dimension of the impact of environmental effects on the learning process and the performance of simple tasks, such as school work is still being studied, however, it is a fact that carrying out academic activities with more confidence would increase the availability of time for other activities, interaction between students, leisure and sports, which are known to aid in the learning process (WARGOCKI ET AL., 2013).

Inadequate environmental conditions in classrooms may be reflected not only in the quality of learning but also in the economy and society. Although the social and economic costs of the results observed in this study have not yet 
been estimated, we suggest that children in classrooms with poor environmental comfort face more difficulty in performing their tasks, requiring more time and dedication from teachers.

\section{Conclusions}

Based on both objective and subjective measures, we conclude that the environment of the analyzed school had poorly distributed and inadequate lighting for the development of school routines. This study provides a basis for the promotion of public policies and the adequate construction of schools and day care centers, as it highlights the need for greater attention to schools' environmental comfort, since a lack of such comfort may be directly reflected in the quality of teaching and learning.

\section{Acknowledgments}

This work was supported by the University of Ceuma - UNICEUMA and the Foundation for Research and Scientific and Technological Development of Maranhão - FAPEMA.

\section{References}

ASSOCIAÇÃO BRASILEIRA DE NORMAS TÉCNICAS. NBR 5413: Iluminância de interiores. Rio de Janeiro: 1992 ASSOCIAÇÃO BRASILEIRA DE NORMAS TÉCNICAS. NBR 15215: Iluminação Natural. Rio de Janeiro: 2004. ASSOCIAÇÃO BRASILEIRA DE NORMAS TÉCNICAS. NBR 5382: Verificação De Iluminância De Interiores. Rio de Janeiro: 1985.

ASSOCIAÇÃO BRASILEIRA DE NORMAS TÉCNICAS. NBR 8995-1: Iluminação Natural. Rio de Janeiro: 2013.

BAKO-BIRO, Z, et al. [Ventilation rates in schools and pupils' performance Build]. Environ. 2012;48,215-233. English

BAREETT, P, et al. [A holistic, multi-level analysis identifying the impact of classroom design on pupils' learning Build]. Environ., 59 (2012), pp. 678-689.

BATISTA, et al. O ambiente que adoece: condições ambientais de trabalho do professor do ensino fundamental. Caderno de Saúde Coletiva. 2010;18(2):234-42.

CASTILLA, N, et al. [Subjective assessment of university classroom environment]. Build. Environ. 2017; $122,72-81$.

CORBELLA, Oscar; YANNAS, Simos. Em Busca de Uma Arquitetura Sustentável Para os Trópicos - Conforto Ambiental. Rio de Janeiro: Revan, 2003.

DAISEY, J.M. et al. [Indoor Air Quality, ventilation and health symptoms in schools: an analysis of existing information Indoor Air], 2003;13,53-64.

DALVITE, B.O. et al. A análise do conforto acústico, térmico e lumínico em escolas da rede pública de Santa Maria, RS. Disc. Scientia. Série: Artes, Letras e Comunicação. 2007;8(1):1-13.

FARIAS, Patrícia Marins. Condições do ambiente de trabalho do professor: avaliação em uma escola municipal de Salvador - Bahia. Dissertação de Mestrado, Faculdade de Medicina, UFBA, Salvador, 2009

FRONTCZAK, M., WARGOCKI, P. [Literature survey on how different factors influence human comfort in indoor environments] Build. Environ. 2011;46,922-937. 
GEMELLI, C. B. Avaliação de conforto térmico, acústico e lumínico de edificação escolar com estratégias sustentáveis e bioclimáticas: o caso da escola municipal de ensino fundamental Frei Pacífico. 2009. 175f. Dissertação (Mestrado em Engenharia Civil) - Universidade Federal do Rio Grande do Sul, Porto Alegre.

Haverinen-Shaughnessy U, R.J. Shaughnessy, E.C. Cole, O. Toyinbo, D.Jet al. [Moschandreas, An assessment of indoor environmental quality in schools andits association with health and performance].Build. Environ. 2015;93,3540.

HERACLEOUS, C., MICHAEL, A., [Assesment of natural lighting performance and visual comfort of educational architecture in Southern Europe]. The case of education schools premises in Cyprus, Energy Build. 2017;140,443-457.

HUNTER, E. J et al. [Teachers and Teaching: speech production accommodations due to changes in the acoustic environment]. Energy Procedia.2015;78:3102-3107.

JUSTER, F.T, et al. [Changing Times of American Youth]: 1981-2003, Institute for Social Research. University of Michigan. Ann Arbor, 2004.

Lee, M.C, et al.[Student learning performance and indoor environmental quality (IEQ) and air conditioned university teaching rooms] Build. Environ. 2012;49,238-244.

MENDELL, M.J. HEATH, G.A. [Do indoor pollutants and thermal conditions in schools influence student performance? A critical review of the literature] Indoor Air, 2004;15,1.27-52.

MOURA, P. H. R. ; CERQUEIRA, P. R. A. ; MEIRELES, K. D. ; SOUZA, L. B. E. ; SEIBERT, C. S. . O conforto ambiental do professor em sala de aula. Revista Produção Acadêmica , v. 2, p. 98-114, 2016.

OCHOA, J. H.; ARAÚJO, D. L.; SATTLER, M. A. Análise do conforto ambiental em salas de aula: Comparação entre dados técnicos e a percepção do usuário. Revista Ambiente Construído, 2012;12,91-114.

RICCIARDI, P., BURATTI, C., [Thermal comfort in open plan offices in northern Italy: an adaptive approach]. Build. Environ. 2012;56,314-320.

SCHNEIDER M. [Do Schools Facilities Affect Students' Performance? National Clearinghouse for Educational Facilities]. Washington, DC.2002.

SERRÃO, Helena de Cássia Pessoa Nogueira. A contribuição da iluminação no aprendizado infantil - estudo de caso das escolas de Ensino Infantil na cidade de João Pessoa, PB, Revista Especialize On-line IPOG - Goiânia - $8^{\mathrm{a}}$ Edição n ${ }^{\circ}$ 009 Vol.01/2014 dezembro/2014.

SHAPIRO, M., ROTH, D., MARCUS, A., [The effect of lighting on the behavior of children who are developmentally disabled]. J. Int. Spec. Needs Educ. 2001;4,19-23.

SOUZA, Ellen Priscila Nunes de. Qualidade da iluminação: influências e impactos na saúde do ser humano. Juiz de Fora, 2012. In: ENTAC 2012 - XIV Encontro Nacional de Tecnologia do Ambiente Construído. Anais... Juiz de Fora, 2012, CD-ROM

TOYINBO, O, et al. [Building characteristics, indoor environmental quality, and mathematical achievement in Finish elementary schools]. Build. Environ. 2016;104,114-121.

VIANNA, Nelson Solano; GONÇALVES, Joana Carla. Iluminação e arquitetura. São Paulo: Virtus, 2001. 362p WARGOCKI, P, Wyon.[Providing better termal and air quality conditions in school class rooms would becost-effective Build]. Environ. 2013;59,581-589.

WINTERBOTTOM, M., WILKINS, A.. [Lighting and discomfort in the classroom] J. Environ. Psycology 2009;29,6375.

ZOMORODIAN, Z.S., et al.[Thermal comfort in educational buildings: a review article, Renew. Sustain.] Energy Rev. 2016;59,895-906. 